\title{
Notes
}

\section{Scoter, Melanitta spp., Migrations Interrupted by Confederation Bridge: An Update}

\author{
KATHERINE BUNKER-POPMA
}

40 Weldon Street, Sackville, New Brunswick E4L 4N4 Canada

Bunker-Popma, Katherine. 2006. Scoter, Melanitta spp., migrations Interrupted by Confederation Bridge: An update. Canadian Field-Naturalist 120(2): 232-233.

Continued monitoring over 10 years of scoter migrations through Northumberland Strait confirmed that these birds continue to perceive the Confederation Bridge (completed in 1997) as an obstacle. Such problems - and alternatives not causing them - need serious consideration when "strait crossings" are contemplated elsewhere.

Key Words: Scoters, Melanitta spp., migrations, Northumberland Strait, bridge, New Brunswick.

While the Confederation Bridge $\left(46^{\circ} 15^{\prime} \mathrm{N}, 63^{\circ} 40^{\prime} \mathrm{W}\right)$ linking Prince Edward Island to New Brunswick was being completed in 1997, Hicklin and Bunker-Popma (2001) examined the possible influence of the bridge upon migration by marine birds. They concluded that migrating scoters (Melanitta spp., seaducks) were unwilling to fly under the (40 metre high) bridge and often reluctant to fly over it.
Earlier information, recently supported by several studies (e.g. Wilson et al. 2003*), suggested that, in recent years at least, most migrating scoters passing through the Maritime Provinces in spring cross the Chignecto Isthmus $40-50 \mathrm{~km}$. further west and do not approach the Confederation Bridge. Much less is known about their fall migrations.

TABLE 1. Ten years of scoter movement at Confederation Bridge, New Brunswick/Prince Edward Island. Spring (S) and fall (F) totals shown separately for each year.

\begin{tabular}{|c|c|c|c|c|c|}
\hline \multirow{2}{*}{$\begin{array}{l}\text { Year } \\
1997\end{array}$} & \multirow{3}{*}{$\begin{array}{l}\mathrm{S} \\
\mathrm{F}\end{array}$} & \multirow{2}{*}{$\begin{array}{c}\begin{array}{c}\text { Observation } \\
\text { time }(\mathrm{hr})\end{array} \\
54\end{array}$} & \multirow{2}{*}{$\begin{array}{c}\text { Scoters seen to } \\
\text { approach bridge }\end{array}$} & \multicolumn{2}{|c|}{$\begin{array}{c}\text { Scoters seen to pass } \\
\text { over bridge* }(\%)\end{array}$} \\
\hline & & & & 243 & (33) \\
\hline & & 102 & 876 & 338 & (39) \\
\hline \multirow[t]{2}{*}{1998} & $\mathrm{~S}$ & 15 & 70 & 29 & (41) \\
\hline & $\mathrm{F}$ & 49 & 923 & 388 & (42) \\
\hline \multirow[t]{2}{*}{1999} & $\mathrm{~S}$ & 4 & 16 & 0 & \\
\hline & $\mathrm{F}$ & 78 & 1495 & 881 & (59) \\
\hline \multirow[t]{2}{*}{2000} & $\mathrm{~S}$ & 35 & 389 & 67 & (17) \\
\hline & $\mathrm{F}$ & 74 & 1675 & 859 & (51) \\
\hline \multirow[t]{2}{*}{2001} & $\mathrm{~S}$ & 16 & 212 & 115 & (54) \\
\hline & $\mathrm{F}$ & 72 & 906 & 431 & (48) \\
\hline \multirow[t]{2}{*}{2002} & $\mathrm{~S}$ & 18 & 461 & 150 & (33) \\
\hline & $\mathrm{F}$ & 70 & 1368 & 725 & (53) \\
\hline \multirow[t]{2}{*}{2003} & $\mathrm{~S}$ & 27 & 604 & 129 & (21) \\
\hline & $\mathrm{F}$ & 50 & 1824 & 1274 & (70) \\
\hline \multirow[t]{2}{*}{2004} & $\mathrm{~S}$ & 28 & 515 & 275 & (53) \\
\hline & $\mathrm{F}$ & 47 & 1253 & 696 & (56) \\
\hline \multirow[t]{2}{*}{2005} & $\mathrm{~S}$ & 11 & 46 & 6 & (13) \\
\hline & $\mathrm{F}$ & 22 & 435 & 156 & (36) \\
\hline \multirow[t]{2}{*}{2006} & $\mathrm{~S}$ & 14 & 124 & 68 & (55) \\
\hline & $\mathrm{F}$ & 40 & 1038 & 547 & (53) \\
\hline \multirow[t]{2}{*}{ Totals } & $\mathrm{S}$ & 222 & 3168 & 1082 & (34) \\
\hline & $\mathrm{F}$ & 604 & 11793 & 6295 & (53) \\
\hline \multicolumn{2}{|c|}{ Grand Totals } & 826 & 14961 & 7377 & (49) \\
\hline
\end{tabular}

* No scoters were seen to pass under the bridge 
I monitored seaduck migrations at Confederation Bridge each year since 1997, using procedures of our original study (Hicklin and Bunker-Popma 2001) to see if these birds habituated to the perceived obstacle. Results of these observations, summarized in Table 1 , suggest that the majority of scoters still, after 10 years, have not learned a simple, general, way of passing the bridge.

Nearly half of those seen (34\% in spring, 53\% in fall) circled upwards and passed extremely high over the bridge without landing. Others landed on the water, and remained there, often for hours. Still others followed the bridge towards the opposite shore, and sometimes were lost to sight while still flying. As my observations do not suggest that birds in the two latter categories stay near the bridge indefinitely, presumably they continue their migrations later, but timing of their departures and the routes followed remain unknown.

Given the small fraction of regional scoter populations that approach it, this bridge cannot be considered a major obstacle to their migrations, at a flyway level. Nevertheless, the continuing problem posed to the birds that encounter this bridge needs to be borne in mind whenever and wherever bridges are proposed in loca- tions traversed by major portions of migratory species populations.

\section{Acknowledgments}

A. J. Erskine edited my original draft and encouraged publication of this update.

Document Cited (marked * in text)

Saint John Naturalists Club, Inc. 2003. Mystery migration: Secret of the Black Scoter (bilingual). Video (23:45 English, 24:15 French); filmed and edited by Rowan Ridge Productions Ltd. (This video refers to several unpublished studies on scoter migrations in the Maritime Provinces).

\section{Literature Cited}

Hicklin, P. W., and K. Bunker-Popma. 2001. The spring and fall migrations of scoters, Melanitta spp., at Confederation Bridge in the Northumberland Strait between New Brunswick and Prince Edward Island. Canadian Field-Naturalist 115: 436-445.

MacKinnon, C., and A. Kennedy. 2006. An observation of the spring 2006 migration of Black Scoter, Melanitta nigra, in Northumberland Strait interrupted by the Confederation Bridge. Canadian Field-Naturalist 120(2): 233-234.

Received 14 December 2004

Accepted 26 February 2007 